Aviram, A., Kenyan, A., and Czaczkes, J. W. (1969). In Dialysis and Renal Transplantation: Proceedings of the 5th Conference of the European Dialysis and Transplant Association, edited by D. N. S Kerr, p. 46. Amsterdam, Excerpta Medicá.

Bennhold, I., Froese, P., Scholz, A.,. and Kessel, M. (1969). In Dialysis and Renal Transplantation: Proceedings of the 5 th Conference of the European Dialysis and Transplant Association, edited by D. N. S. Kerr, p. 50 . Amsterdam, Excerpta Medica.

Brescia, M. J., Cimino, J. E., Appel, K., and Hurwich, B. J. (1966). New England Fournal of Medicine, 275, 1089.

Clarke, P. B., and Parsons, F. M. (1966). British Medical fournal, 1, 1200 .

Clunie, G. J. A., Martin, A. M., and Nolan, B. (1967). British Medical fournal, 3, 88 .

Comty, C. M., Baillod, R. A., Crockett, R., and Shaldon, S. (1967). In Replacement of Renal Function: Proceedings of the 3rd Confer ence of the European Dialysis and Transplant Association, edited by D. N. S. Kerr, p. 98 . Amsterdam, Excerpta Medica.

De Palma, J. R., Golding, A., and Maxwell, M. H. (1969). Transactions. American Society for Artificial Internal Organs, 15, 278

Drukker, W., Schouten, W. A. G., and Alberts, C. H. R. (1969). In Dialysis and Renal Transplantation: Proceedings of the 5th Conference of the European Dialysis and Transplant Association, edited ence of the European Dialysis and Transplant Associ.
by D. N. S. Kerr, p. 3. Amsterdam, Excerpta Medica.

Fritzer, W., Jahn, O., and Pinggera, W. (1968). In Dialysis and Renal Transplantation: Proceedings of the 4 th Conference of the European Dialysis and Transplant Association, edited by D. N. S. Kerr, p. 366. Amsterdam, Excerpta Medica.

Glashan, R. W., and Walker, F. (1968). British fournal of Surgery, 55, 189.

Gombos, E. A., Hendler, E. D., and Hendler, R. G. (1968). In Dialysis and Renal Transplantation: Proceedings of the 4th Conference of the European Dialysis and Transplant Association, edited by the European Dialysis and Transplant Association,

Hawkins, J. B., and Robinson, B. H. B. (1967). British Medical fournal, $4,226$.

Hegstrom, R. M., Quinton, W. E., Dillard, D. H., Cole, J. J., and Scribner, B. H. (1961). Transactions. American Society for Artificial Internal Organs, 7, 47.

Hoeltzenbein, J. (1968). In Dialysis and Renal Transplantation: Procedings of the 4th Conference of the European Dialysis and Trans plant Association, edited by D. N. S. Kerr, p. 39. Amsterdam, Excerpta Medica.

Hoeltzenbein, J. (1969). In Dialysis and Renal Transplantation: Proceedings of the 5th Conference of the European Dialysis and Transplant Association, edited by D. N. S. Kerr, p. 370. Amsterdam, Excerpta Medica.
Kjellstrand, C. M., Lindergård, B., and Boijsen, E. (1968). In Dialysis and Renal Transplantation: Proceedings of the $4 \mathrm{th}$ Conference of the European Dialysis and Transplant Association, edited by D. N. S. Kerr, p. 61. Amsterdam, Excerpta Medica.

Kopp, K. F., Crossman, D. F., and Frey, J. (1968). In Dialysis and Renal Transplantation: Proceedings of the 4th Conference of the European Dialysis and Transplant Association, edited by D. N. S. Kerr, p. 373. Amsterdam, Excerpta Medica.

Kulatilake, A. E. (1968). In Dialysis and Renal Transplantation: Proceedings of the 4th Conference of the European Dialysis and Transplant Association, edited by D. N. S. Kerr, p. 369 . Amsterdam, plant Association,

McDonald, H., jun, and Waterhouse, K. (1967). In Replacement of Renal Function: Proceedings of the 3rd Conference of the European Dialysis and Transplant Association, edited by D. N. S. Kerr, p. 337. Amsterdam, Excerpta Medica.

Mayall, G. F. (1964). Clinical Radiology, 15, 355.

Papadimitriou, M., Carrol, R. N. P., and Kulatilake, A. E. (1969). British Medical łournal, 2, 15.

Pendras, J. P., and Smith, M. P. (1966). Transactions. American Society for Artificial Internal Organs, 12, 222.

Quinton, W. E., Dillard, D. H., Cole, J. J., and Scribner, B. H. (1961). Transactions. American Societs for Artificial Internal Organs, 7, 60.

Quinton, W. E., Dillard, D. H., Cole, J. J., and Scribner, B. H. (1962) Transactions, American Society for Artificial Internal Organs, 8 ,

Ramirez, O., Swartz, C., Onesti, G., Mailloux, L., and Brest, A. N. (1966). Transactions. American Society for Artificial Internal Organs, 12, 220

Rentan, J. W., and Lewis, H. Y. (1966). Annals of Internal Medicine, 64, 284.

Scribner, B. H., Caner, J. E. Z., Buri, R., and Quinton, W. E. (1969). In Proceedings of the 6th Conference of the European Dialysis and Transplant Association. In press.

Sevitt, L., Comty, C., Rottka, H., and Shaldon, S. (1964). In Proceedings of the 1st Conference of the European Dialysis and Transplant Association, edited by D. N. S. Kerr, p. 271. Amsterdam, Scheltema and Hdima.

Sinclair, D. J. (1968). Clinical Radiology, 19, 287.

Vermylen, J., Amery, A., Dirix, R., and Verstraete, M. (1967). Lancet, 2, 1369 .

Wing, A. J., Curtis, J. R., and de Wardener, H. E. (1967a). British Medical fournal, 3, 143.

Wing, A. J., Curtis, J. R., de Wardener, H. E., and Evans, D. B. (1967b) In Replacement of Renal Function: Proceedings of the 3rd Conference of the European Dialysis and Transplant Association, edited by D. N. S. Kerr, p. 102. Amsterdam, Excerpta Medica.

\title{
Impact of Community-orientated Psychiatry on Marriage and Fertility of Psychotic Women
}

\author{
BARBARA STEVENS,* B.A., PH.D.
}

Summary : A large representative sample of psychotic $S$ women of reproductive age was selected from patients admitted to a London mental hospital during 1955-63 and followed up during the years of developing community care. Before first admission the probability of marriage of schizophrenics was three-quarters of that of corresponding normal women, and after admission it was just over one-third of normal. Fertility of schizophrenics was slightly reduced both before and after illness, and much of this reduction remains due to their being in hospital. The probability of marriage and fertility of women suffering from severe affective disorders was very similar to that found in the corresponding general population. Despite a lessening of differentials between patients and normal women since the impact of community care the probability of marriage of schizophrenics with abnormal personalities is still significantly reduced.

- Member of the Scientific Staff, M.R.C. Social Psychiatry Research Unit, Institute of Psychiatry, London S.E.5.

\section{Introduction}

During the first half of this century long-term institutional care characterized the lives of the mentally ill, and their probability of marriage and fertility appeared to be reduced when compared with the corresponding general population. In Germany Kallmann (1938) selected over 1,000 schizophrenics from patients admitted to a Berlin hospital between 1893 and 1902 , and followed them up until 1933 ; the proportion who eventually married was well below that expected on the basis of Berlin's general population, except among those with paranoid schizophrenia whose illness was of late onset. The fertility of non-paranoid schizophrenics was also below that of the general population. Essen-Möller (1935) analysed a large series of patients admitted to the Munich Psychiatric Clinic between 1904 and 1927, and found that the probability of marriage of schizophrenics after admission was between one-third and oneninth of that of the general population. The fertility of schizophrenics was low before the spread of birth control, and even after the fall in the German birth rate it was especially low 
after admission. Patients with manic-depressive psychosis had a probability of marriage of half of normal after admission, but their fertility did not appear to be as reduced as that of those with schizophrenia.

More recently Ødegård (1960) studied patients admitted to Norwegian hospitals between 1936 and 1955, and showed that it is the low probability of marriage before illness which accounts for the low total fertility of schizophrenics. Manicdepressives appeared to have a slightly lower fertility within marriage, but their probability of marriage was almost that of normal women, so that their fertility was considerably higher than that of schizophrenics.

In New York State Erlenmeyer-Kimling, Rainer, and Kallmann (1966) compared the fertility of schizophrenics who were admitted during 1934-6 and followed up until 1941 with that of patients admitted in 1954-6 who were followed up until 1961. Since the developments in treatment and community care (during the later period) the fertility differential between patients and normal women appeared to be disappearing, though the proportion of schizophrenics who married remained low. Births after admission increased as a percentage of total fertility in the post-war sample, probably because of shorter periods in hospital: preliminary results indicated that $43.4 \%$ of the earlier sample were admitted to hospital compared with only $20.7 \%$ of women in the later sample.

The aim of the present inquiry was to estimate the probability of marriage and fertility of women suffering from schizophrenia and affective disorders since the impact of community orientated psychiatry in England.

\section{Methods}

Method of Sample Selection.-The sample was composed of all the women of reproductive age who were admitted during 1955-63 to a large London mental hospital for the treatment of schizophrenia, mania, or severe depression.

Method of Collecting Data.-(a) Detailed clinical and social histories were collected from case records. (b) After discharge the patients were followed up by post, according to methods suggested by Laurence (1959). Patients, relatives, general practitioners, and other hospitals were contacted, and $80 \%$ of the original sample were traced. There were no serious sources of non-response bias.

Method of Measuring Probability of Marriage.-Owing to the demographic heterogeneity of the sample it was decided that the method of analysis with maximum discriminative power would be to compare each patient with a normal woman of corresponding age observed during identical calendar periods. Probabilities of marriage of normal women were derived from the Registrar General's estimates. It was necessary to solve maximum likelihood equations by iterative methods on the Atlas computer in order to determine the appropriate mathematical models for such a controlled analysis of marriage. The periods in the patients' lives before first admission were analysed separately from the periods after admission.

Method of Measuring Legitimate Fertility.-Calculations of the mean family size of each clinical group, controlled for age at marriage, calendar date of marriage, and duration of marriage were compared with the Registrar General's data on the general population. The separate analysis of fertility after admission was essentially designed to measure the effect of stay in hospital on reducing exposure to conception. A special calculation, however, was also made of the fertility of the general population adjusted to exclude births to normal women which would have been conceived during the patients' time in hospital, in order to detect any reductions in fertility of the patients that were independent of the effect of the hospital stay.

The results were analysed for all races of patients, but as there appeared to be a slight bias towards Southern Irish,
Polish, and coloured immigrants it was necessary to analyse British non-coloured patients separately to arrive at more reliable comparisons with the Registrar General's data.

\section{Results}

Tables I, II, and III give the most reliable results based on the analysis of British non-coloured patients.

Probability of Marriage Before Admission.-Table I shows that whereas the probability of marriage of schizophrenics was reduced before admission the women suffering from affective

TABLB I.-Probability of Marriage Before Admission of Women Suffering from Schizophrenia or Affective Disorders: Probabilities Probability to that of Corresponding Normal Women: British White Patients Only

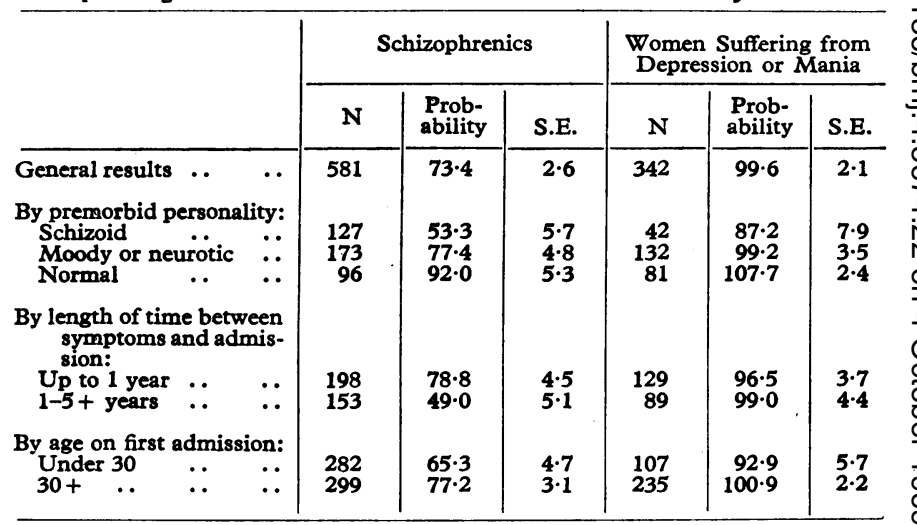

disorders were very similar to the general population regarding chance of marriage. Within the schizophrenic group the patients with schizoid personalities and those experiencing a long period of symptoms before admission were significantly less likely to marry than others at the $1 \%$ level. Schizophrenics admitted before they were 30 had a reduced chance of marriage compared with older patients on first admission; this differential was significant at the $5 \%$ level.

Probability of Marriage After Admission (Table II).-Schizophrenics had a greatly reduced chance of marriage of one-third of normal during this period, whereas women suffering from

TABLE II.-Probability of Marriage After Admission According to Premorbid Personality, Number of Admissions, Total Length of Stay in Hospital, and Course of Illness*

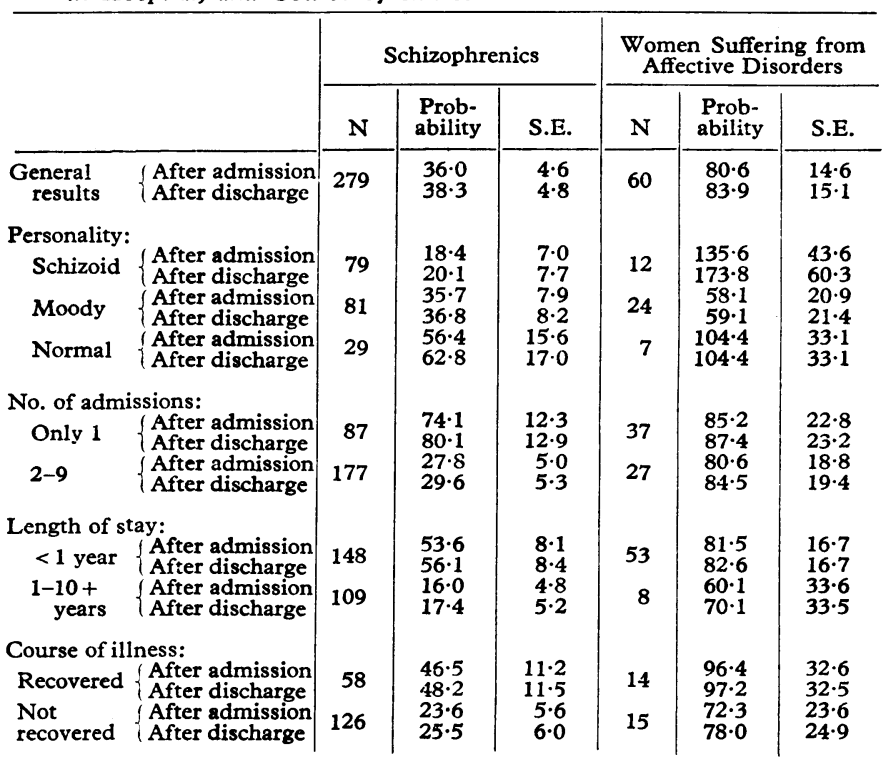

* Probabilities expressed as the ratio of the patients' probability to that of corresponding normal women. 
TABLE III.-Legitimate Fertility after Admission of Women Suffering from Schizophremia and Affective Disorders by Length of Hospital Stay and Course of Illness

\begin{tabular}{|c|c|c|c|c|c|c|c|c|c|c|c|}
\hline & & \multicolumn{5}{|c|}{ Schizophrenics } & \multicolumn{5}{|c|}{ Women with affective disorders } \\
\hline & & $\mathbf{N}$ & $\begin{array}{l}\text { Actual } \\
\text { Mean } \\
\text { Family } \\
\text { Size }\end{array}$ & S.E. & $\begin{array}{l}\text { Expected } \\
\text { Mean }\end{array}$ & $\begin{array}{l}\text { Ratio of } \\
\text { Actual- } \\
\text { Expected } \\
\text { to S.E. }\end{array}$ & $\mathbf{N}$ & $\begin{array}{l}\text { Actual } \\
\text { Mean } \\
\text { Family } \\
\text { Size }\end{array}$ & S.E. & $\underset{\text { Mean }}{\text { Expected }}$ & $\begin{array}{l}\text { Ratio of } \\
\text { Actual- } \\
\text { Expected } \\
\text { to S.E. }\end{array}$ \\
\hline $\begin{array}{c}\text { General } \\
\text { results }\end{array}$ & $\begin{array}{l}\text { After admission } \\
\text { After discharge }\end{array}$ & $\begin{array}{l}265 \\
256\end{array}$ & $\begin{array}{l}0 \cdot 37 \\
0 \cdot 38\end{array}$ & $\begin{array}{l}0.05 \\
0.05\end{array}$ & $\begin{array}{l}0.52 \\
0.43\end{array}$ & $\begin{array}{l}-3.00 \\
-1 \cdot 13\end{array}$ & $\begin{array}{l}221 \\
211\end{array}$ & $\begin{array}{l}0 \cdot 31 \\
0 \cdot 30\end{array}$ & $\begin{array}{l}0.05 \\
0.05\end{array}$ & $\begin{array}{l}0.39 \\
0.33\end{array}$ & $\begin{array}{l}-1.62 \\
-0.74\end{array}$ \\
\hline \multicolumn{12}{|c|}{ Length of stay: } \\
\hline $\begin{array}{c}<1 \text { year } \\
1-10+ \\
\text { years }\end{array}$ & $\begin{array}{l}\text { After admission } \\
\text { After discharge } \\
\text { After admission } \\
\text { i After discharge }\end{array}$ & $\begin{array}{r}152 \\
151 \\
89 \\
87\end{array}$ & $\begin{array}{l}0.26 \\
0.26 \\
0.44 \\
0.45\end{array}$ & $\begin{array}{l}0.05 \\
0.05 \\
0.11 \\
0.11\end{array}$ & $\begin{array}{l}0.43 \\
0.39 \\
0.63 \\
0.48\end{array}$ & $\begin{array}{r}-3 \cdot 16 \\
-2 \cdot 51 \\
-1 \cdot 79 \\
0.31\end{array}$ & $\begin{array}{r}171 \\
168 \\
28 \\
28\end{array}$ & $\begin{array}{l}0.29 \\
0.29 \\
0.07 \\
0.07\end{array}$ & $\begin{array}{l}0.06 \\
0.06 \\
0.05 \\
0.05\end{array}$ & $\begin{array}{l}0.32 \\
0.30 \\
0.60 \\
0.48\end{array}$ & $\begin{array}{r}-0.64 \\
-0.17 \\
-10.81 \\
-8.37\end{array}$ \\
\hline \multicolumn{12}{|c|}{ Course of illness: } \\
\hline $\begin{array}{l}\text { Recovered } \\
\text { Not } \\
\text { recovered }\end{array}$ & $\begin{array}{l}\text { After admission } \\
\text { After discharge } \\
\text { After admission } \\
\text { After discharge }\end{array}$ & $\begin{array}{l}67 \\
66 \\
95 \\
94\end{array}$ & $\begin{array}{l}0.30 \\
0 \cdot 30 \\
0.34 \\
0 \cdot 34\end{array}$ & $\begin{array}{l}0.09 \\
0.10 \\
0.07 \\
0.07\end{array}$ & $\begin{array}{l}0.40 \\
0.38 \\
0.55 \\
0.44\end{array}$ & $\begin{array}{r}-1 \cdot 11 \\
-0 \cdot 78 \\
-3 \cdot 10 \\
1.38\end{array}$ & $\begin{array}{l}52 \\
50 \\
83 \\
80\end{array}$ & $\begin{array}{l}0 \cdot 40 \\
0 \cdot 42 \\
0 \cdot 28 \\
0 \cdot 28\end{array}$ & $\begin{array}{l}0 \cdot 13 \\
0 \cdot 13 \\
0.07 \\
0 \cdot 08\end{array}$ & $\begin{array}{l}0 \cdot 34 \\
0 \cdot 31 \\
0 \cdot 37 \\
0 \cdot 30\end{array}$ & $\begin{array}{r}0.52 \\
0.84 \\
-1.25 \\
-0.28\end{array}$ \\
\hline
\end{tabular}

* Source of general population data: the Registrar General's Annual Statistical Review for England and Wales, Part II, Table PP.

affective disorders had only a slightly reduced probability of marriage. Within the schizophrenic group the patients of schizoid personality, those requiring two or more admissions, and those who had required a total of over one year in hospital were significantly less likely to marry than others at the $1 \%$ level. The women suffering from affective disorders are an older group, most of whom married before admission, so that few were available for a first marriage after admission. It would appear that this group does not differ very significantly from normal women in chance of marriage after discharge.

Legitimate Fertility.-Before admission, British non-coloured schizophrenics had a mean family size of $1.36 \pm 0.07$ compared with 1.54 expected among normal women of corresponding age and duration of marriage; this indicated a reduction in fertility which clearly was statistically significant but too small to be sociologically important. Women with affective disorders had a mean of $1.60 \pm 0.07$ compared with 1.64 children expected, which was not a significant difference.

Table III shows that after admission the schizophrenics had a reduced fertility which depended on the effect of a stay in hospital in reducing exposure to conception. Analysis by total length of time in hospital, however, indicated that short-stay schizophrenics have a significantly reduced fertility which is quite independent of the effect of admission to hospital-that is, probably due to birth control or marital discord. Schizophrenics who did not recover had a significantly reduced fertility, which depended on the effect of stay in hospital, whereas those who recovered did not have a significantly reduced fertility. It should be emphasized that none of these differences in fertility were large enough to be clinically or sociologically important.

\section{Discussion}

The total fertility of schizophrenics remains low in spite of developments in community care, as described, for example, by Brown, Bone, Dalison, and Wing (1966) and Freeman and Farndale (1967). This is mainly because of the low probability of marriage of schizophrenics before and after illness. The significant factor of schizoid personality in reducing the chance of marriage was clearly demonstrated, and such differentials will probably remain, however much community care is developed. The results on the period after admission indicated that, today, patients with chronic schizophrenia have a greatly reduced chance of marriage, but this is not as low as EssenMöller (1935) found under the old regimen of custodial care.

The legitimate fertility of schizophrenics is still significantly low, both before and after admission, but owing to the widespread practice of birth control any fertility differentials are too small to be clinically or sociologically important, and this agrees with the results of Erlenmeyer-Kimling et al. (1966) in America. Though much of the reduction in fertility was due to admission to hospital, short-stay schizophrenics had a low fertility quite independent of this factor, and this may be due to birth control practised because of the effect of the psychosis on family life. Women with affective disorders appear to marry and bear children as frequently as normal women, and it would seem that the differentials found by Essen-Möller after admission have disappeared now that community care and antidepressant and other drugs are widely used.

The present results are of relevance to the genetic theory of schizophrenia in that there remains a need to explain the continuing high incidence of the disorder in spite of reduced reproductive fitness. Monogenic theories are unsatisfactory because they suggest mutation rates above Haldane's estimates for human genes (Erlenmeyer-Kimling and Paradowski, 1966). Gottesmann and Shields's (1967) polygenic theory is more appropriate in allowing lower mutation rates at different loci, and in assuming that many individuals may contribute to the gene pool who are not phenotypically abnormal enough to be selected against in marriage.

A fuller account of the present survey (including results on illegitimate births, and on marital breakdown) may be found in a book to be published (Stevens, 1969).

I wish to thank the Medical Research Council for the Mapother Research Fellowship ; Professor Sir Aubrey Lewis, Professor D. V. Glass, and Mr. N. H. Carrier for excellent advice; and Dr. H. C. Beccle and Dr. Morris Markowe for facilities provided at Springfield Hospital, London. This research was part of a Ph.D. thesis of London University, 1967.

\section{REFERENCES}

Brown G. W., Bone, M., Dalison, B., and Wing, J. K. (1966). Schizophrenia and Social Care. London, Oxford University Press.

Erlenmeyer-Kimling, L., and Paradowski, W. (1966). The American Naturalist, 100, 651.

Erlenmeyer-Kimling, L., Rainer, J. D., and Kallmann, F. J. (1966). In Psychopathology of Schizophrenia, edited by P. D. Hoch and J. Zubin, p. 252. New York, Grune and Stratton.

Essen-Möller, E. (1935). Acta Psychiatrica et Neurologica, Suppl. No. 8. Freeman, H., and Farndale, J. (editors) (1967). New Aspects of the Mental Health Services. Oxford, Pergamon.

Gottesmann, I. I., and Shields, J. (1967). Proceedings of the National Academy of Sciences, 58, 199.

Kallmann, F. J. (1938). The Genetics of Schizophrenia. New York, Augustin.

Laurence, K. M. (1959). Lancet, 2, 208.

Ødegård, Ø. (1960). International fournal of Social Psychiatry, 6, 25.

Stevens, B. C. (1969). Marriage and Fertility of Women Suffering from Schizothrenia or Affective Disorders. In press. 